\title{
WOOD-BASED PANELS INDUSTRY IN TURKEY: FUTURE RAW MATERIAL CHALLENGES AND SUGGESTIONS
}

\author{
Hasan Tezcan Yıldırım ${ }^{1, \star}$, Zeki Candan'2, Süleyman Korkut ${ }^{3}$
}

In memoriam of Dr. Manfred SCHWANNINGER

\begin{abstract}
World production of wood based panel has grown from 63,1 million cubic meters in 2005 to 75,5 million $\mathrm{m}^{3}$ in 2009, a 12 million $\mathrm{m}^{3}$ rise in production. China is the world's largest wood based panel's manufacturer. The Turkish wood based panels industry has shown a tendency of fluctuating during this time. Turkey, as the world's $4^{\text {th }}$ largest producer of wood based panels, is an important contributor to the industry. Turkey has made great strides in the last 20 years in the forest products industry. Both the development of new materials and techniques of domestic and international market demand have played a decisive role. Turkey's wood panel production has gone from $100000 \mathrm{~m}^{3}$ in the early $2000 \mathrm{~s}$, to 5,5 million $\mathrm{m}^{3}$ of production in 2010. The sector's total production capacity is approximately 9 million $\mathrm{m}^{3}$. The results obtained thus far indicate that the Turkish wood based panel industry demand for raw material is not being met by the GDF's chip wood fiber production. Where the raw material supply problem in the industry, as well as the problems encountered in the forest and on the basis of the villagers living adjacent to, not to the time of product problems related to storage and transportation of raw materials and other related problems are bottlenecks. We examine problems related to the provision of raw materials and raw materials research, the need for future estimates of the level at which the world and close to the periphery countries will be examined, wood composite panel production and trade policy recommendations will be developed.
\end{abstract}

Keywords: Wood based panels industry, forest industry, forest products, forest products policy, forest villagers

\section{INTRODUCTION}

The forest products industry has been an inevitable propelling power of economy since olden times (Mahapatra and Mitchell 1997, Ok 2005, İlter and Ok 2007, Paul and Chakrabarti 2011). Thus, industrial use of wood is important from the past through today. Use of wood as an industrial material is perceived as a source of income for wood producers (Cubbage et al. 2007, Toppinen and Kuuluvainan 2010, Damette and Delacote 2011). Meeting wood demand is of great importance to the forestry sector. The fact that the wood demand is still being met via illegal methods today highlights the relevance of sustainable forest management, specifically the practice of certification for industrial wood production (Schanz 2002, Hetemäki and Nilsson 2005, Krott 2005, Ingold and Zimmermann 2011). The board sector of the wood industry has made a giant leap forward, especially in the last ten years. The most important reason for this progress is the fact that the economic value of wood decreases when used in its unaltered form (Y1ldirım 2010, Espinoza et al. 2011, Zhou et al. 2012). In recent years the use of wood-based panels such as fiberboard, particleboard, oriented strandboard, plywood etc., for several applications has been gaining great importance due to their properties (Ustaömer and Usta 2012).

\footnotetext{
'Department of Forest Engineering, Istanbul University, Istanbul, 34473 Turkey;

${ }^{2}$ Department of Forest Products Engineering, Istanbul University, Istanbul, 34473 Turkey;

${ }^{3}$ Department of Forest Products Engineering, Düzce University, Düzce, 81620 Turkey

^Corresponding author: htezcan@istanbul.edu.tr

Received: 02.12. 2012 Accepted: 18.07. 2013
} 
Worldwide board production fluctuated between 2005 and 2009 with an increase from 63,1 million $\mathrm{m}^{3}$ in 2005 to 75,5 million $\mathrm{m}^{3}$ in 2009. The world's largest board producer, China, fulfills $45 \%$ of worldwide board production alone. The USA, Germany and Turkey follow China, which produced 34,5 million $\mathrm{m}^{3}$ of boards in 2009. As the 4th largest board producer worldwide, Turkey is an important country for the sector (Y1ldirım 2010). From this perspective, it is essential to discuss the current status of the sector and that of the resources owned by Turkey.

According to the latest forest inventory research and management plans made by forestry organization, Turkey has a total of 21,2 million ha of forested area (which corresponds to $25 \%$ of country's surface area). Of these 21,2 million ha, it is estimated that 10,1 million serve an economic function 10,4 million serve an ecologic function, and 0,7 million ha serve social functions (General Directorate of Forestry (GDF), 2006). Fifteen million ha of forests are groves while 6 million ha are coppice woodlands. Around $60 \%$ of the forests are normal while $40 \%$ is degraded forests. Over $99 \%$ of the Country's forests are owned by the state while the surface area of forests owned by public legal persons is approximately 7986 ha. The surface area of forests owned by the private sector, exclusive of special afforestation practices using poplar and other species, is 10182 ha. According to GDF's data (2008), total growing stock of Turkey's forests is 1,2 billion $\mathrm{m}^{3}$ in normal forests and 0.8 billion $\mathrm{m}^{3}$ in degraded forests. Average growing stock per unit area for normal forests is $112,5 \mathrm{~m}^{3} / \mathrm{ha}$ and $8,28 \mathrm{~m}^{3} /$ ha for degraded forests. While the growth of Turkey's forests was 36,3 million $\mathrm{m}^{3}$, the yearly allowable cut given in management plans was 16,3 million $\mathrm{m}^{3}$. Increase is $3,34 \mathrm{~m}^{3} / \mathrm{ha}$ totals in normal forests in unit surface area and $0,23 \mathrm{~m}^{3} / \mathrm{ha}$ total in degraded forests. A major portion of industrial wood production consists of small diameter and low value product (fiber-chip, wood for paper production and industrial wood). First and second class rate in lumber, which is also classified as industrial wood, is calculated to be 3\% (GDF 2008). It is estimated that in Turkey, 150000 to 200000 ha is used for growing poplar, approximately 3,0-3,5 million $\mathrm{m}^{3}$ is used for meeting the industrial wood requirement annually, and 2 million $\mathrm{m}^{3}$ is used as firing wood (Kaplan 2008).

For the purpose of meeting the total wood requirement, GDF supplies 12-13 million $\mathrm{m}^{3}$ wood from their sales to the market, 2-3 million $\mathrm{m}^{3}$ is produced by the private sector, and 2.3 million $\mathrm{m}^{3}$ is supplied to the market via imports (GDF 2011). The remaining balance of 4-5 million $\mathrm{m}^{3}$ is known to be supplied illegally. Although some substitute materials, such as metallics and synthetics, are widely used today, this does not mitigate the need for wood products. To the contrary, consumption of wood products is rapidly increasing with increasing worldwide economic development and population growth (Birler 1998, Ekizoğlu 2008, Toppinen and Kuuluvainan 2010, Yıldırım 2010, Erol 2012). The board sector of the forest industry is of great importance for Turkey. While wood can be an export item once processed, new factories are opened and new employment opportunities arise as the sector grows.

Turkey has achieved major progress in the forest industry, especially in the last 20 years. The board sector is at the forefront of this progress. Both the development of new material techniques and the demand in domestic and international markets have had decisive roles in such progress (Ekizoğlu and Yildırım 2011). Turkey's board production was $100000 \mathrm{~m}^{3}$ in early 2000s, production increased to 5,5 million $\mathrm{m}^{3}$ level as of 2010 . There are 40 facilities in the sector, 24 of which produce chip board while 16 facilities produce fiber board. Total production capacity of the sector is approximately 9 million $\mathrm{m}^{3}$. Rapid development of the sector has certain complications. In a general sense, these complications are as follows (Ekizoğlu 1985, Zengin 2009, Yildırım, 2010).

\section{Raw Material Issue}

The single biggest cost factor for the chip board and fiber board industry is wood material. Accordingly, raw material issues are among the most important problems for the industry. As an example, the actual capacity of chip board industry requires approximately $7824000 \mathrm{~m}^{3}$ raw materials and the fiber board industry requires $10676000 \mathrm{~m}^{3}$ for an overall raw material requirement of around $18500000 \mathrm{~m}^{3}$. This will pave the way for imports, which in turn cause losses to the country's economy. Import raw material 
requirement of the board sector, which suffers a raw material shortage in the current situation, will increase after these investments.

\section{Purpose of Use Issues}

The chip board and fiber board industries are able to use raw materials of both high and low quality. The quality of raw material used in these sectors is close to that used in the paper industry. Firing wood and waste raw materials of other forest products can be used in the board industry at certain proportions. However, the fact that raw material suitable for use by the chip board and fiber board sectors is being distributed to forest villagers for firing wood gives rise to an important raw material problem for the board industry.

\section{Transportation Issue}

Transportation, namely freight transportation, causes two problems for board sector. First is the inability of transporting raw materials. Second is the fact that transportation is a cost factor that increases the overall cost of raw materials. Transportation's contribution to overall cost increases with the transportation distance. Although exact percentages are unknown, increasing raw material costs result in an increase in final product prices which make it difficult to achieve stability in market prices.

\section{Technical Personnel Issue}

The fact that forest industry engineers in particular do not have a sufficient level of material knowledge by the time of graduation causes major problems in the factory work environment. It is not possible for employers to cover up such insufficiencies of engineers, and therefore providing employment opportunities in production lines of work to forest industry engineers becomes more difficult.

The purpose of this study is to project the future demand of raw materials based on government past board sector data to bring solutions and recommendations to known issues. Two distinct scenarios were developed for the purpose of demand projection. While only the yearly change was considered in the first scenario, anticipated demand calculated on the basis of socio-economic variables was considered in the second scenario.

\section{MATERIALS AND METHODS}

Cases where a dependent variable can be calculated using a single independent variable is very rare. In particular, the planning and management of forest resources is multi-dimensional in nature. Accordingly, multidimensional decision taking methods are suitable for the structure of forest resources and more substantial decisions and solution propositions are possible when these methods are used (Daşdemir and Güngör 2002). The most widely used and most suitable technique for multidimensional decision taking methods, as well as in forestry studies, is regression (Altunışık et al. 2002, Yazıcıoğlu and Erdoğan 2004, Kalaycı 2006). A multi-dimensional linear regression model was used to analyze the data of this research. Future demand was estimated for raw wood materials used in board production via multiple regressions. Moreover, wood requirement was determined considering Turkey's current board production and predictions on the amount of raw materials to be needed in the future are listed.

In the event of a linear relationship $(\mathrm{Y}=\mathrm{a}+\mathrm{bx})$ between an independent variable and a dependent variable, the forecast method will be presented as a linear equality. Mathematical formula is obtained based on the previous year's values of the dependent variable with the help of a linear relation formula to bring out the relationship between independent and dependent variables. On the other hand, if the relationship between dependent and independent variables or the time series formed, is parabolic $(\mathrm{Y}=\mathrm{a}+/-$ bx+/-cx2), then the forecast method used will be parabolic equality (Kalıpsız 1994, Kalayc1 2006, İlter and Ok 2007). This way, in the first stage, independent variable values are defined which will be used to explain the dependent variable values in coming years, and industrial demand forecasts are determined by using the values of independent variables in the second stage. A Dublin-Watson test was used to 
determine if there is any auto correlation between the variables for linear regression analysis (Kalayc1 2006, İlter and Ok 2007). A calculated value near to zero indicates a positive correlation, while a value such as 2 indicates no correlation, and a value such as 4 indicates negative correlation (Şencan 2005, Altunışık et al. 2007).

The socioeconomic variables used in this study included the amount of industrial wood production used in board production between 1980 and 2010 (WP), population (PPL), Gross Domestic Product per capita in US dollars on basis of current producer prices (GDP\$), and number of completed buildings (NoCB). Data pertaining to these variables were taken from General Directorate of Forestry (GDF), Turkish Statistical Institute (TSI), Istanbul Chamber of Commerce (ICC) and State Planning Agency and are given in table 1 below.

Table 1. Values of independent variables between 1980 and 2010.

\begin{tabular}{|c|c|c|c|c|}
\hline Years & WP & PPL & GDP\$ & NoCB \\
\hline 1980 & 6796950 & 44736957 & 1539 & 63301 \\
\hline 1981 & 7312423 & 45922457 & 1570 & 57232 \\
\hline 1982 & 5839416 & 47107957 & 1375 & 54156 \\
\hline 1983 & 6683409 & 48293457 & 1264 & 54532 \\
\hline 1984 & 7614403 & 49478957 & 1204 & 57201 \\
\hline 1985 & 7425396 & 50664458 & 1330 & 52183 \\
\hline 1986 & 7570000 & 51826173 & 1462 & 71461 \\
\hline 1987 & 7251000 & 52987888 & 1636 & 80520 \\
\hline 1988 & 7447000 & 54149603 & 1684 & 83714 \\
\hline 1989 & 7460000 & 55311318 & 1959 & 94799 \\
\hline 1990 & 6581000 & 56473035 & 2682 & 94489 \\
\hline 1991 & 6513000 & 57606124 & 2621 & 92388 \\
\hline 1992 & 6897000 & 58739213 & 2708 & 105293 \\
\hline 1993 & 7010000 & 59872302 & 3004 & 101712 \\
\hline 1994 & 6712000 & 61005391 & 2184 & 99993 \\
\hline 1995 & 8046000 & 62138480 & 2759 & 96661 \\
\hline 1996 & 7528000 & 63271569 & 2928 & 104776 \\
\hline 1997 & 6974000 & 64404658 & 3079 & 106406 \\
\hline 1998 & 7051000 & 65537747 & 4168 & 91816 \\
\hline 1999 & 7066000 & 66670836 & 3739 & 86777 \\
\hline 2000 & 7329000 & 67803927 & 3914 & 90849 \\
\hline 2001 & 6777671 & 68201403 & 2878 & 86155 \\
\hline 2002 & 8005138 & 68598879 & 3326 & 47094 \\
\hline 2003 & 7320498 & 68996355 & 4341 & 50140 \\
\hline 2004 & 8253000 & 69393831 & 5487 & 75495 \\
\hline 2005 & 8100284 & 69791307 & 6681 & 114254 \\
\hline 2006 & 9298696 & 70188783 & 7214 & 114204 \\
\hline 2007 & 10053000 & 70586256 & 9212 & 105865 \\
\hline 2008 & 11542000 & 71517100 & 8507 & 93013 \\
\hline 2009 & 11464000 & 72561312 & 9318 & 93493 \\
\hline 2010 & 12570000 & 73722988 & 10190 & 93961 \\
\hline
\end{tabular}




\section{RESULTS}

Multi linear regression modeling has been used to forecast the industrial wood production demand. Data, obtained from time series and mathematical methods, has been used to form this model. Industrial wood production demand quantities were estimated by adding the forecasted values of independent variables on the basis model which belong to the years of 2011-2023 into their place in demand forecast model. Simple regression models and the models were calculated with the help of MS Excel. Based on changes in the population, gross domestic product per capita in US dollars on basis of current producer prices and number of completed buildings according to years, and that are simple regression formulas in figure $1 \mathrm{a}$, figure $1 \mathrm{~b}$ and figure $1 \mathrm{c}$. 


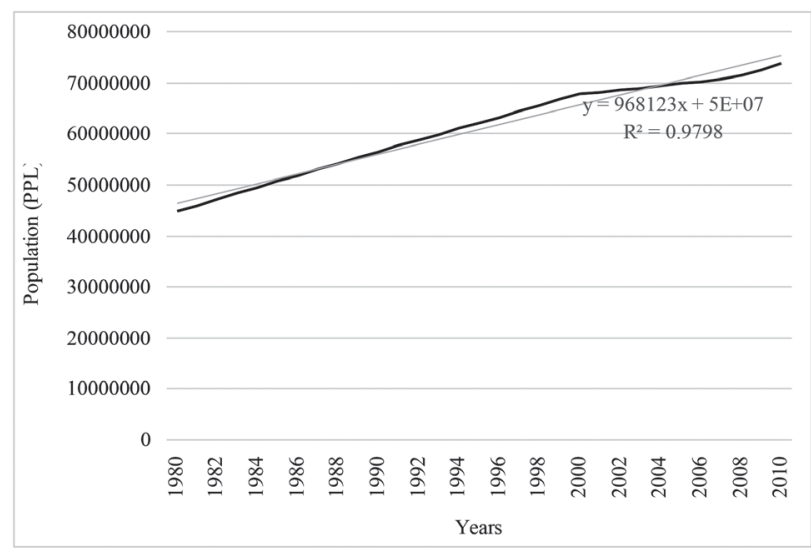

(a)

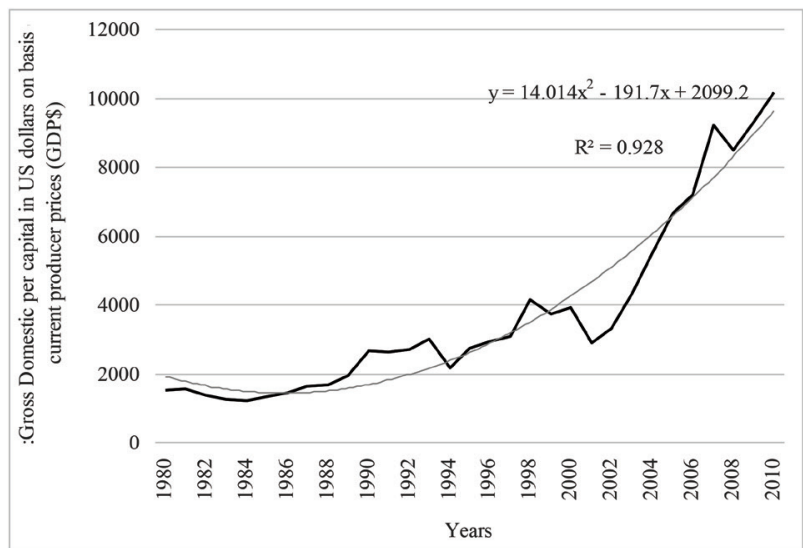

(b)

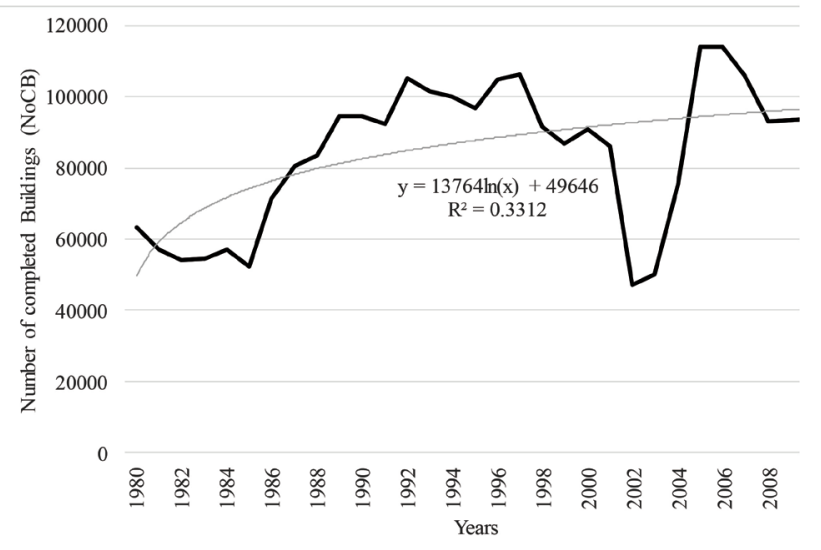

Figura 1. (a) Population changes and its simple regression model; (b) Gross Domestic Product changes and its simple regression model; (c) Number of completed buildings changes and its simple regression model.

Their values are determined from the 2011-2023 models with the help of the variables shown in table 2. In table $2, \mathrm{R}^{2}$ values, Durbin-Watson values, $\mathrm{F}$ value, significant value, $\mathrm{T}$ value $(\mathrm{t}$ test), regression formulas, and forecasted values are displayed for the period of 2011-2023. 
Table 2. Forecast values of the variables used for predicting of industrial wood production demand quantity (2011-2023).

\begin{tabular}{|c|c|c|c|}
\hline Year & PPL & GDP\$ (US Dolars) & NoCB \\
\hline $\mathrm{R}^{2}$ & 0,98 & 0,92 & 0,33 \\
\hline DW & 0,062 & 0,272 & 0,142 \\
\hline $\mathrm{F}$ & 1406,581 & 104,098 & 9,407 \\
\hline Sig. & 0,000 & 0,000 & 0,005 \\
\hline t-test & 37,504 & 10,203 & 3,067 \\
\hline Formula & $\mathrm{Y}_{\mathrm{PPL}}=968,123 *($ Year $)+45 \mathrm{E}+06$ & $\begin{array}{c}\mathrm{Y}_{\mathrm{GDP}}=14.347 *(\text { Year })^{2}- \\
190 *(\text { Year })+2050,7\end{array}$ & $\begin{array}{c}\mathrm{Y}_{\mathrm{NoCB}}=13,764 * \ln (\text { Year })+49 \\
646\end{array}$ \\
\hline 2011 & $75,979,936$ & 10,655 & 97,348 \\
\hline 2012 & $76,948,059$ & 11,397 & 97,772 \\
\hline 2013 & $77,916,182$ & 12,168 & 98,183 \\
\hline 2014 & $78,884,305$ & 12,967 & 98,582 \\
\hline 2015 & $79,852,428$ & 13,795 & 98,970 \\
\hline 2016 & $80,820,551$ & 14,652 & 99,347 \\
\hline 2017 & $81,788,674$ & 15,538 & 99,714 \\
\hline 2018 & $82,756,797$ & 16,452 & 100,071 \\
\hline 2019 & $83,724,920$ & 17,395 & 100,420 \\
\hline 2020 & $84,693,043$ & 18,366 & 100,760 \\
\hline 2021 & $85,661,166$ & 19,366 & 101,091 \\
\hline 2022 & $86,629,289$ & 20,395 & 101,415 \\
\hline 2023 & $87,597,412$ & 21,453 & 101,732 \\
\hline
\end{tabular}

Multiple regression method was used in order to determine the board production volume and future demand. The percentage of the independent variables' ability to explain the dependent variable is given in table 3.

Table 3. Model Summary.

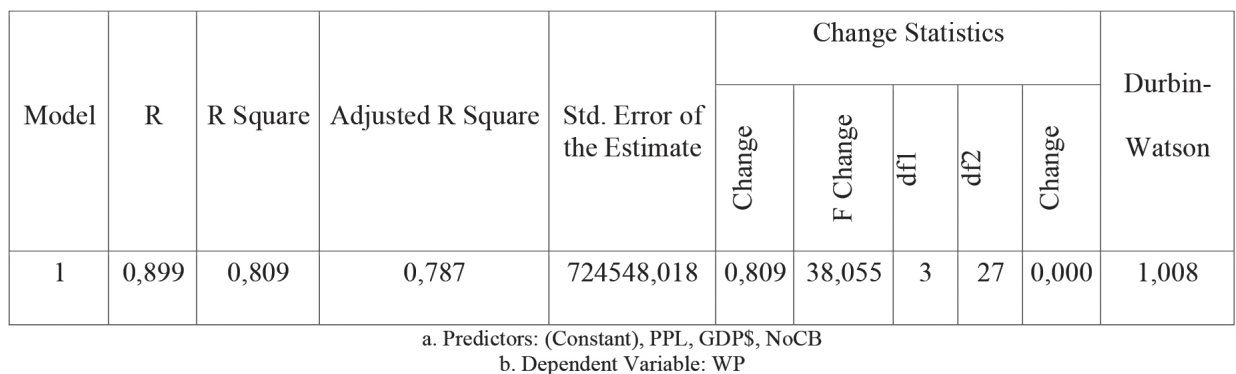


We see that independent variables explain the dependent variable by $80.9 \%$ in the model regression analysis summary to determine the amount of industrial wood needed for board production. The model's significance level is 0,000 which indicates there is a significant correlation (at 0,001 levels) between independent variables included in the model and dependent variable. The model for purpose of determining the industrial wood production volume was formulated based on the data given in table 4 .

Table 4. Model data used in projection of industrial wood production volume.

\begin{tabular}{|c|c|c|c|c|c|c|}
\hline \multicolumn{2}{|c|}{ Model } & \multicolumn{2}{|c|}{ Unstandardized Coefficients } & $\begin{array}{c}\text { Standardized } \\
\text { Coefficients }\end{array}$ & t & Sig. \\
\cline { 2 - 7 } & B & Std. Error & Beta & \\
\hline \multirow{2}{*}{1} & (Constant) & 8951462,088 & 1339600,008 & & 6,682 & 0,000 \\
\cline { 2 - 7 } & PPL & $-0,049$ & 0,027 & $-0,276$ & $-1,805$ & 0,082 \\
\cline { 2 - 7 } & GDP\$ & 651,333 & 83,173 & 1,147 & 7,831 & 0,000 \\
\cline { 2 - 7 } & NoCB & $-7,703$ & 7,588 & $-0,100$ & $-1,015$ & 0,319 \\
\hline
\end{tabular}

In accordance with the data given in table 4, industrial wood production model is formulated as follows.

$$
\mathrm{Y}=8951462,088-0049 * \mathrm{PPL}+651333 * \text { GDP\$-7,703* NoCB }
$$

With the help of this formula, it is understood that industrial wood production is directly correlated to changes in population and Gross Domestic Product and inversely correlated to number of completed buildings. Independent variables' values for years between 2011 and 2023 have been calculated using simple regression and used in corresponding years in multiple regressions analysis models. Industrial wood production volume was found on basis of these calculations and given in table 5 . 
Table 5. Projection of industrial wood production in the future.

\begin{tabular}{|c|c|}
\hline Years & $\begin{array}{c}\text { Projection of industrial wood } \\
\text { production }\left(\mathrm{m}^{3}\right) \text { with } \\
\text { regression model }\end{array}$ \\
\hline 2011 & 11277520 \\
\hline 2012 & 11723508 \\
\hline 2013 & 12189674 \\
\hline 2014 & 12674626 \\
\hline 2015 & 13179046 \\
\hline 2016 & 13702934 \\
\hline 2017 & 14246974 \\
\hline 2018 & 14809780 \\
\hline 2019 & 15392719 \\
\hline 2020 & 15994416 \\
\hline 2021 & 16615564 \\
\hline 2022 & 17256834 \\
\hline 2023 & 17917536 \\
\hline
\end{tabular}

According to Chip Board Industrialists Association (2012) data Chip Board Factories in Turkey have an established capacity of $17427 \mathrm{~m}^{3} /$ day and an actual daily production of $14437 \mathrm{~m}^{3}\left(5269505 \mathrm{~m}^{3}\right.$ per year). On the other hand, capacity of established and active fiberboard mills is $13,645 \mathrm{~m}^{3} /$ day $(4980425$ $\mathrm{m}^{3} /$ year). The yearly wood requirement for active capacities (as opposed to that of the established capacities) is 10,4 million $\mathrm{m}^{3}$ of wood for chip board. Likewise, wood needed for fiber board is 15 million $\mathrm{m}^{3}$. Therefore, Turkey's wood requirement for the board sector alone is approximately 25 million $\mathrm{m}^{3}$. Current production volume is 11.3 million $\mathrm{m}^{3}$ in our calculations and 7 million $\mathrm{m}^{3}$ firewood that totally 18 million $\mathrm{m}^{3}$. Turkey has to use imports for forest industry sector. It is understood that this volume is insufficient today and a production of such limited volume will not meet future requirements for wood based panels industry.

\section{CONCLUSIONS}

Recommendations to alleviate the problems encountered in board production, and predictions on the future, are given below in light of the findings of the study:

In order to meet the industrial wood demand, it is essential to carry out initial demand forecasts and to revisit forecasts each year.

Industrial plantation operations for the purpose of meeting the needs of forest industry must be accelerated as the demand will increase in the future.

Generalization of sustainable forest management and certification practices and prediction of future certified wood demand are essential.

New practices to increase the productivity of Turkey's forests must be accelerated. Silvicultural practices, which are of great relevance in meeting the quantitative wood demands of the forest industry in particular, must be prioritized. In this context, shortening the management periods, especially in relation to red pine, can be considered as an option. 
It is essential to identify areas to be used for wood production in the scope of functional planning, to carry out practices in accordance with such planning, and to review management plans.

We shouldn't delay in fulfilling the requirements of sustainable forest management and international processes must be considered while deciding on wood production policies.

Material knowledge, management and organization issues must have greater focus in education of Forest Industry Engineers.

Allocations made for forest villagers must be reviewed with due consideration to the future of the forest industry.

Because the raw material requirements of the sector will increase due to new initiatives in the future, both the private sector and state must launch afforestation practices, in particular using quick developing species, nearby factories of large capacities. Red Pine and Poplar, which are able to adapt in Turkey's conditions, may be preferred as quick developing species.

Furthermore another important result presented that the content of legal arrangements is less comprehensive than national plans and programs.

While $18,4 \%$ of the total assessed expressions take place in legal based documents and the rests are observed in 9th Development Plan Forestry Expert Commission Report and National Forestry Program.

Then it could be suggested that the legal background of the forestry oriented rural development issues should be strengthened and enriched.

\section{ACKNOWLEDGMENTS}

The authors are grateful for the support of the Istanbul University Scientific Research Projects, Grant. No. N-18864

\section{REFERENCES}

Altunışık, R.; Coşkun, R.; Yıldırım, E.; Bayraktaroğlu, S. 2002. Sosyal Bilimlerde Araştırma Yöntemleri SPSS Uygulamalı (Research Methods in Social Sciences Applied with SPSS). Sakarya Kitabevi, ISBN 975-8644-07-6. İkinci Baskı. Sakarya, Turkey.

Birler, A.S. 1998. Endüstriyel Plantasyonlar (Orman Ağaçları Tarımı) (Industrial PlantationFarmforestry). Çevre ve İnsan. Anadolu Üniversitesi Açıköğretim Fakültesi Yayınları. Anadolu Üniversitesi Yayın No: 1017, Açıöğretim Fakültesi Yayın No: 560, Bölüm 9, 175-188. Eskişehir, Turkey.

Chip Board Industrialists Association, CBIA. 2012. Statistics about Chip Board Industries in Turkey (Unpubleshed). CBIA database. İstanbul, Turkey.

Cubbage, F.; Mac Donagh, P.; Sawinski-Júnior, J.; Rubilar, R.; Donoso, P.; Ferreira, A.; Hoeflich, V.; Morales-Olmos, V.; Ferreira, G.; Balmelli, G.; Siry, J.; Báez, M.; Alvarez, J. 2007. Timber investment returns for selected plantation and native forests in South America and the Southern United States. New Forests 33(3):237-255.

Damette, O.; Delacote, P. 2011. Unsustainable timber harvesting, deforestation and the role of certification. Ecological Economics 70(6):1211-1219

Daşdemir, İ.; Güngör, E. 2002. Çok Boyutlu Karar Verme Metotları ve Ormancılıkta Uygulama Alanları" (Multivariate Decision-Making Methods and Their Using Areas in Forestry) ZKÜ Bartın Orman Fakültesi Dergisi 4:1-19. Bartın, Turkey. 
Ekizoğlu, A. 1985. Türkiye'de Yonga Levha Endüstrisi Sorunları ve Çözüm Yolları (Particle Board Industry Problems and Solutions in Turkey). PhD Thesis, İstanbul, Turkey.

Ekizoğlu, A. 2008. Orman Endüstri Politikası Ders Notları (Forest Industry Policy Lecture Notes (Unpublished). İstanbul, Turkey.

Ekizoğlu, A.; Yildirim H.T. 2011. Orman Endüstri Politikası Ders Notları (Forest Industry Policy Lecture Notes (Unpublished). İstanbul, Turkey.

Erol, Y. S. 2012. Differences between urban and rural population with respect to demand on forestry aspects, in a case study of the Turkish province of Balıkesir. Ciência Rural, Santa Maria 42(3): 436-443.

Espinoza, O.; Buehlmann, U.; Bumgardner, M.; Smith, B. 2011. Assessing changes in the U.S. hardwood sawmill industry with a focus on markets and distribution. BioResources 6(3): 2676-2689.

Hetemäki, L.; Nilsson, S. (Eds.). 2005. Information Technology and the Forest Sector. IUFRO World Series, Vol. 18

Ingold, K.; Zimmermann, W. 2011. How and why forest managers adapt to socio-economic changes: a case study analysis in Swiss forest enterprises. Forest Policy and Economics 13: 97-103.

İlter, E.; Ok, K. 2007. Ormancıllk ve Orman Endüstrisinde Pazarlama Illkeleri ve Yönetimi (Forestry and Forest Industry Marketing Principles and Management). Ankara, Turkey.

Kalaycı, S. 2006. SPSS Uygulamalı Çok Değişkenli İstatistik Teknikleri 2 (Multivariate Statistical Techniques Applied with SPSS 2). ISBN: 975-9091-14-3. Bask1, Asil Yayın Dağıtım, Ankara, Turkey.

Kalıpsız, A. 1994. İstatistik Yöntemler. İ.Ü. Orman Fakültesi, Üniversite Yayın No: 3835, Fakülte Yayın No: 427, 558 s. İstanbul, Turkey.

Kaplan, E. 2008. Türkiye'de Orman Ürünleri Talebi ile Arz Kaynaklarının Değerlendirilmesi ve Endüstriyel Plantasyonların Yeri (Assessment of Demand for Forest Products and Supply Resources and the Place of Industrial Plantations in Turkey). 150th Anniversary of Forestry Education in Turkey: Bottlenecks, Solutions, and Priorities in the Context of Functions of Forest Resources / 17-19 October 2007, İstanbul, Turkey.

Krott, M. 2005. Forest Policy Analysis. (e-book). ISBN: 978-1-4020-3478-7 (Print) 978-1-40203485-5 [Online] <http://link.springer.com/book/10.1007/1-4020-3485-7/page/1 >

Mahapatra, A.; Mitchell, C.P. 1997. Sustainable development of non-timber forest products: implication for forest Management in India. Forest Ecology and Management 94: 15-29.

GDF. 2006. Ministry of Forestry Annual Statistic Database. [online]. [Date: 08.05.2012] <www. ogm.gov.tr>

GDF. 2008. Evaluation of Production and Marketing Activities 2008. [online] [Date: 08.05.2012] $<$ www.ogm.gov.tr $>$.

GDF. 2011. General Directorate of Forestry Annual Report 2010, Ankara, Turkey.

Ok, K. 2005. Idea Marketing in Forestry: Some Implications from the Turkish Forestry Experience. Forest Policy and Economics 7(4): 493-500. 
Paul, S.; Chakrabarti, S. 2011. Socio-economic issues in forest management in India. Forest Policy and Economics 13(1): 55-60.

Schanz, H. 2002. National forest programmes as discursive institutions. Forest Policy and Economics 4(4): 269-279.

Şencan, H. 2005. Sosyal ve davranışsal ölçümlerde güvenilirlik ve geçerlilik. 1.Bask1, 867p, ISBN: 9789753478847. Seçkin Yayınevi. Ankara, Turkey.

Toppinen, A.; Kuuluvainan, J. 2010. Forest sector modeling in Europe. State of art and Future, Helsinki University.

Ustaömer, D.; Usta, M. 2012. The effects of boron compounds and different melamine contents in MUF resins on some properties of MDF panels. BioResources 7(1): 437-446.

Yazıcıoğlu, Y.; Erdoğan, S. 2004. SPSS Uygulamalı Bilimsel Araştırma Yöntemleri (Scientific Research Methods Applied with SPSS), ISBN: 975-8326-98-8, Detay Yayınc1lı, Ankara, Turkey.

Yıldırım, H.T. 2010. Türkiye'de odun üretim tüketim ilişkilerinin ormancılık politikası açısından irdelenmesi (Examination of Wood Production-Consumption Relations in Terms of Forest Policy in Turkey). İ.Ü. Fen Bilimleri Enstitüsü Doktora Tezi (PhD Thesis) (Unpublished), İstanbul, Turkey.

Zengin, H. 2009. Yonga Levha ve Lif Levha Endüstrisinde Odun Hammaddesi Sağlanması Sorunları ve Çözüm Yolları. (Problems and Solutions on Providing Wood Raw Material in Sheet and Plate Chip Industries) İ.Ü. Fen Bilimleri Enstitüsü Yüksek Lisans Tezi (Master Thesis)(Yayımlanmamış). Istanbul, Turkey.

Zhou, J.; Hu, C.; Hu, S.; Yun, H.; Jiang, G.; Zhang, S. 2012. Effects of temperature on the bending performance of wood-based panels. BioResources 7(3): 3597-3606. 